\title{
Discovery and characterization of a peptide that enhances endosomal escape of delivered proteins in vitro and in vivo
}

\section{Citation}

Li, Margie, Yong Tao, Yilai Shu, Jonathan R. LaRochelle, Angela Steinauer, David Thompson, Alanna Schepartz, Zheng-Yi Chen, and David R. Liu. 2015. Discovery and characterization of a peptide that enhances endosomal escape of delivered proteins in vitro and in vivo. Journal of the American Chemical Society 137, no. 44: 14084-14093. doi:10.1021/jacs.5b05694.

\section{Published Version}

doi:10.1021/jacs.5b05694

\section{Permanent link}

http://nrs.harvard.edu/urn-3:HUL.InstRepos:27413829

\section{Terms of Use}

This article was downloaded from Harvard University's DASH repository, and is made available under the terms and conditions applicable to Open Access Policy Articles, as set forth at http:// nrs.harvard.edu/urn-3:HUL.InstRepos:dash.current.terms-of-use\#OAP

\section{Share Your Story}

The Harvard community has made this article openly available.

Please share how this access benefits you. Submit a story.

Accessibility 


\section{INTRODUCTION}

Proteins that bind extracellular targets, including monoclonal antibodies ${ }^{1}, \mathrm{Fc}$ fusions ${ }^{2}$, and cytokines ${ }^{3}$, have served as important therapeutics ${ }^{4}$. Fully realizing the therapeutic potential of proteins, however, requires methods to enable exogenous proteins to access intracellular targets. Because the vast majority of proteins cannot spontaneously cross cell membranes, the development of intracellular protein delivery methods could facilitate applications including enzyme replacement therapies for metabolic diseases ${ }^{5}$, transcription factor-driven changes in cell fate ${ }^{6}$, and genome editing 7 .

Several methods for protein delivery have been explored in the past decade, including cell-penetrating peptides $(\mathrm{CPPs})^{8}$, penta-arg proteins ${ }^{9}$, receptor ligands ${ }^{10}$, and lipid nanoparticles ${ }^{11}$. While these and other methods have advanced the field of protein delivery, challenges including cytotoxicity, lack of generality, low potency, or poor in vivo activity continue to limit their therapeutic relevance $^{12,13}$.
We previously reported the discovery of superpositivelycharged proteins, a class of engineered and naturally occurring proteins that have abnormally high net positive charge, and their ability to potently deliver proteins and nucleic acids into mammalian cells ${ }^{14-17}$. While superpositive proteins are very efficiently endocytosed $^{18,19}$ and can be more effective for protein delivery than $\mathrm{CPPs}^{15}$, the vast majority of endocytosed proteins remain sequestered in endosomes ${ }^{18}$ that either mature into lysosomes, resulting in protein degradation, or are recycled to the surface of the cell ${ }^{20}$, resulting in extracellular protein release (Figure 1A). As a result, relatively high concentrations $(\mu \mathrm{M})$ of exogenous protein are typically needed for modest cytosolic or nuclear delivery. Although superpositively charged proteins can slow endosomal maturation ${ }^{18}$, the inefficiency of endosomal escape enables only a small fraction of delivered protein to reach the cytosol ${ }^{21}$.

To address this protein delivery bottleneck, we sought to discover peptides that facilitate endosomal escape when fused to endocytosed superpositively charged proteins such as +36 GFP. 
Membrane-active peptides such as influenza-derived HA2 have been reported to be endosomolytic ${ }^{22}$. However, many of these peptides, including HA2, are cytotoxic at concentrations required for protein delivery ${ }^{23,24}$. Antimicrobial peptides (AMPs) are a class of membrane-active peptides that penetrate microbial membranes to provide defense against bacteria, fungi, and viruses, often with high selectivity ${ }^{25}$. Given that many AMPs exhibit minimal toxicity to mammalian cells $\mathrm{s}^{26}$, we hypothesized that the altered endosomal environment or endosomal membrane curvature could induce some AMPs to be endosomolytic without exhibiting significant mammalian cell toxicity at useful concentrations. To test this hypothesis, we performed a screen of AMPs for their ability to increase protein delivery into the cytosol.

\section{A}

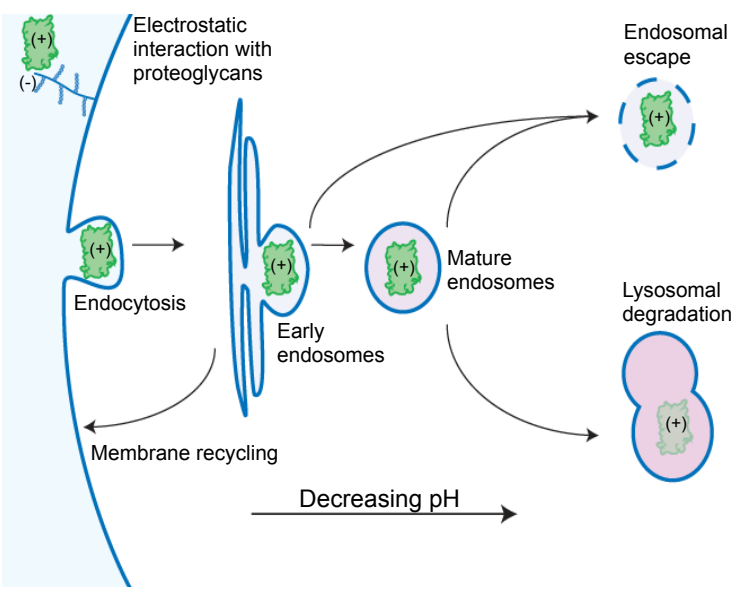

B

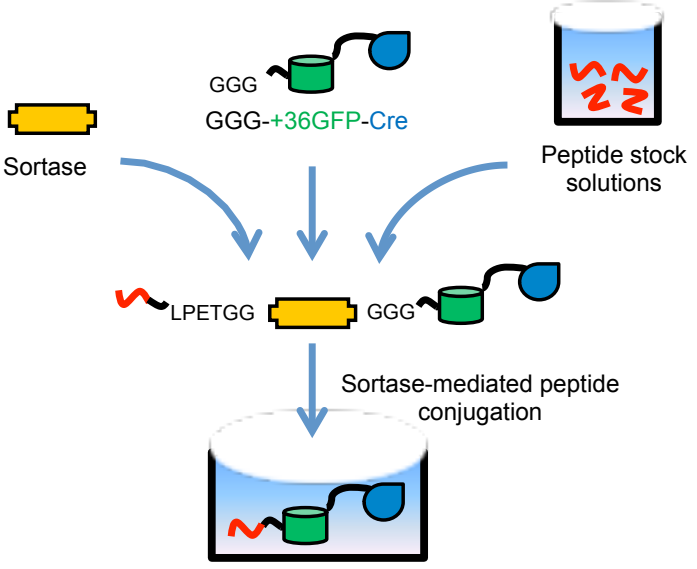

Figure 1. (A) Overview of protein delivery in mammalian cells. Cationic macromolecules such as +36 GFP interact with anionic sulfated proteoglycans on the cell surface and are endocytosed and sequestered in early endosomes. The early endosomes can acidify into late endosomes or lysosomes. Alternatively, early endosomes may be trafficked back to the cell surface as part of the membrane-recycling pathway. To access the cytoplasm, an exogenous cationic protein must escape endosomes before it is degraded or exported. (B) Sortase-mediated conjugation of peptides with $+36 \mathrm{GFP}-\mathrm{Cre}$ recombinase prior to screening. Sortase was used to conjugate synthetic peptides containing a Cterminal LPETGG with expressed +36 GFP-Cre containing an Nterminal GGG. The resulting peptide-LPETGGG-+36 GFP-Cre fusion proteins have the same chemical composition as expressed recombinant proteins, but are more easily assembled.
A major challenge to developing agents that enhance endosomal escape is the lack of well-established assays that can distinguish proteins trapped in the endosomes from proteins released into the cytosol. Commonly used enzyme delivery assays involve substrates and products that can freely diffuse through membranes and cannot differentiate between endosomal and cytosolic proteins. To overcome this challenge, we used multiple independent assays that reflect the interaction of a variety of cargo with a variety of cytosolic targets to evaluate endosomal escape of AMP-protein fusions.

In this study, we discovered aurein 1.2 (GLFDIIKKIAESF) as a peptide that enhances the endosomal escape of a variety of cargo fused to +36 GFP. We elucidated structure-function relationships within aurein 1.2 using alanine scanning and mutational analysis. Results from three independent delivery assays confirmed that treatment of mammalian cells with cargo proteins fused to aurein $1.2-+36$ GFP result in more efficient cytosolic delivery than the same proteins fused to +36 GFP alone. Finally, we describe the ability of aurein 1.2 to enhance non-endosomal protein delivery in vivo. Cre recombinase enzyme was delivered into hair cells in the cochlea (inner ear) of live mice with much greater ( $>20$-fold) potency when fused with aurein 1.2 than in the absence of the peptide. These results together provide a simple molecular strategy for enhancing the cytosolic delivery of proteins in cell culture and in vivo that is genetically encoded, localized to cargo molecules, and does not require global treatment with cytotoxic small molecules.

\section{RESULTS}

Preparation of antimicrobial peptide conjugates of supercharged GFP-Cre fusion proteins. We sought AMPs from the Antimicrobial Peptide Database ${ }^{27}$ that are $\leq 25$ amino acids long (to facilitate their preparation and conjugation to +36 GFP), lack post-translational modifications, and are not known to be toxic to mammalian cells. Based on these criteria, we identified 36 AMPs ranging from 9 to 25 amino acids in length (Table 1). Each of the peptides was synthesized on solid phase with an LPETGG sequence appended to their C-terminus to enable sortase-catalyzed conjugation $^{28}$ (Figure 1B). Assembly of proteins using sortase proved more amenable to rapid screening than the construction and expression of the corresponding fusions, especially since several AMP fusions do not express efficiently in E. coli.

The peptides were conjugated to purified GGG-(+36 GFP)Cre using our previously described evolved sortase A enzyme $(\mathrm{eSrtA})^{28}$. Sortase catalyzes the transpeptidation between a substrate containing the C-terminal LPETGG and a substrate containing an $\mathrm{N}$-terminal glycine to form a native peptide bond linkage and a protein identical to the product of translational fusion.

Table 1. List of peptides chosen from the Antimicrobial Peptide Database (APD)

\begin{tabular}{llll}
\hline Label & APD number & Sequence & $\begin{array}{l}\text { Conjugation } \\
\text { efficiency }\end{array}$ \\
\hline A & AP00408 & FLFPLITSFLSKVL & $55 \%$ \\
B & AP00405-11 & FISAIASMLGKFL & $70 \%$ \\
C & AP00327 & GWFDVVKHIASAV & - \\
D & AP01434 & FFGSVLKLIPKIL & - \\
E & AP00013 & GLFDIIKKIAESF & $77 \%$ \\
F & AP00025 & HGVSGHGQHGVHG & $20 \%$ \\
G & AP00094 & FLPLIGRVLSGIL & -
\end{tabular}




\begin{tabular}{ll} 
GLFDIIKKIAESI & $28 \%$ \\
GLLDIVKKVVGAFGSL & - \\
GLFIVKKVVGALGSL & $13 \%$ \\
GLFDIVKKVVGAIGSL & - \\
GLFDIVKKVVGTLAGL & $18 \%$ \\
GLFDIVKKVVGAFGSL & - \\
GLFDIAKKVIGVIGSL & - \\
GLFDIVKKIAGHIAGSI & - \\
GLFDIVKKIAGHIASSI & - \\
GLFIVKKIAGHIVSSI & - \\
FVQWFSKFLGRIL & $51 \%$ \\
GLFDVIKKVASVIGGL & $11 \%$ \\
GLFDIIKKVASVVGGL & - \\
GLFDIIKKVASVIGGL & $4 \%$ \\
VWPLGLVICKALKIC & $4 \%$ \\
NFLGTLVNLAKKIL & $34 \%$ \\
FLPLIGKILGTIL & $14 \%$ \\
FLPIIAKVLSGLL & $86 \%$ \\
FLPIVGKLLSGLL & - \\
FLSSIGKILGNLL & $88 \%$ \\
FLSGIVGMLGKLF & $70 \%$ \\
TPFKLSLHL & $81 \%$ \\
GILDAIKAIAKAAG & $20 \%$ \\
LFDIIKKIAESF & $63 \%$ \\
LFDIIKKIAESGFLFDIIKKIAESF & - \\
GLLNGLALRLGKRALKKIIKRLCR & - \\
GHHHHHHHHHHHHH & - \\
FKCRRWQWRM & $42 \%$ \\
KTCENLADTY & - \\
\hline
\end{tabular}

Peptides were synthesized with a C-terminal LPETGG tag to enable conjugation with an evolved sortase (eSrtA). Conjugation efficiencies were calculated based on LC-MS results using peak abundance as determined through MaxEnt protein deconvolution.

The efficiency of eSrtA-mediated conjugation varied widely among the peptides (Supporting Information Figure S1). Of the 36 peptides chosen for screening, 20 showed detectable ( $4 \%$ to $88 \%$ ) sortase-mediated conjugation to $+36 \mathrm{GFP}-\mathrm{Cre}$, as observed by LC-MS, to generate desired peptide-LPETGGG- $(+36$ GFP $)-C r e$ fusion proteins (Table 1). Unreacted peptide was removed by ultrafiltration with a $30-\mathrm{kD}$ molecular weight cut off membrane.

Primary screen for endosomal escape. We assayed the ability of each peptide-(+36 GFP)-Cre recombinase fusion when added to culture media to effect recombination in BSR.LNL.tdTomato cells $^{15}$, a hamster kidney cell line derived from BHK-21 (Supporting Information Figure S2). Because Cre recombinase must enter the cell, escape endosomes, enter the nucleus, and catalyze recombination to generate tdTomato fluorescence, this assay reflects the availability of active, non-endosomal recombinase enzyme that reaches the nucleus. As a positive control, we treated cells with +36 GFP-Cre and chloroquine, a known endosome-disrupting small molecule ${ }^{29}$.

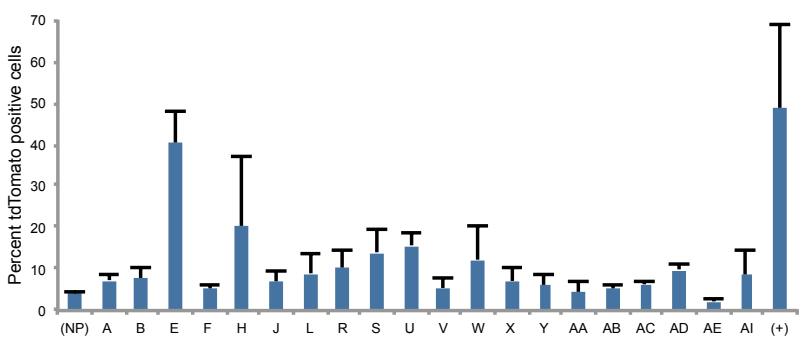

Figure 2. Primary screen for cytosolic delivery of Cre recombinase in BSR.LNL.tdTomato cells. Initial screen of 20 peptide-(+36 GFP) Cre conjugated proteins. Cytosolic Cre delivery results in recombination and tdTomato expression. The percentage of tdTomato positive cells was determined by fluorescence image analysis. $250 \mathrm{nM}+36$ GFP-Cre was used as the no-peptide control (NP), and addition of $100 \mu \mathrm{M}$ chloroquine was used as the positive control (+). Cells were treated with $250 \mathrm{nM}$ protein for $4 \mathrm{~h}$ in serum-free DMEM. Cells were washed and supplanted with full DMEM and incubated for $48 \mathrm{~h}$. Error bars represent the standard deviation of three independent biological replicates.

The reporter BSR.LNL.tdTomato cells were incubated with $250 \mathrm{nM}$ of each peptide-(+36 GFP)-Cre protein in serum-free media. In the absence of any conjugated peptide, treatment of reporter cells with $250 \mathrm{nM}+36 \mathrm{GFP}-\mathrm{Cre}$ protein resulted in $4.5 \%$ of the cells expressing tdTomato, consistent with previous reports ${ }^{18}$. The same concentration of protein incubated with $100 \mu \mathrm{M}$ chloroquine as a positive control resulted in an average of $48 \%$ recombined cells (Figure 2). The results of chloroquine treatment varied substantially between independent replicates. As chloroquine is known to be toxic to cells above $100 \mu \mathrm{M}$, we speculate that this variability arises from the small differences between chloroquine's efficacious and toxic dosages.

Ten of the screened peptide conjugates resulted in recombination efficiencies that were significantly above that of +36 GFP-Cre (Figure 2). The most potent functional delivery of Cre was observed with aurein $1.2-+36$ GFP-Cre (Table 1, entry E). Treatment with aurein $1.2-+36$ GFP-Cre resulted in an average of $40 \%$ recombined cells, comparable to that of the chloroquine positive control (Figure 2). To investigate the impact of differential conjugation efficiency on peptide performance, we compared citropin 1.3 (Table 1, entry $\mathrm{U}$ ), which displayed a moderate level of recombination and the lowest level of conjugation (4\%), to aurein 1.2, which has the highest level of recombination and also a high level of conjugation (77\%).

Both aurein 1.2-+36 GFP-Cre and citropin 1.3-+36 GFP-Cre were cloned, expressed, and purified as fusion proteins. The recombination signal from treatment with $250 \mathrm{nM}$ of expressed aurein 1.2-+36 GFP-Cre was 10.4-fold above that of +36 GFP-Cre. In contrast, treatment with $250 \mathrm{nM}$ expressed citropin 1.3-+36 GFP-Cre did not induce any enhanced Cre delivery. When the treatment concentration was increased to $1 \mu \mathrm{M}$, aurein $1.2-+36$ GFP-Cre and citropin 1.3-+36 GFP-Cre resulted in 3.8-fold and 3.0-fold higher recombination levels, respectively, than that of +36 GFP-Cre alone (Figure 3A). These results suggest that while aurein 1.2 and citropin 1.3 both enhance the delivery of functional, non-endosomal +36 GFP-Cre protein at high concentrations, aurein 1.2 has greater efficacy than citropin 1.3 at lower concentrations. 


\section{A}

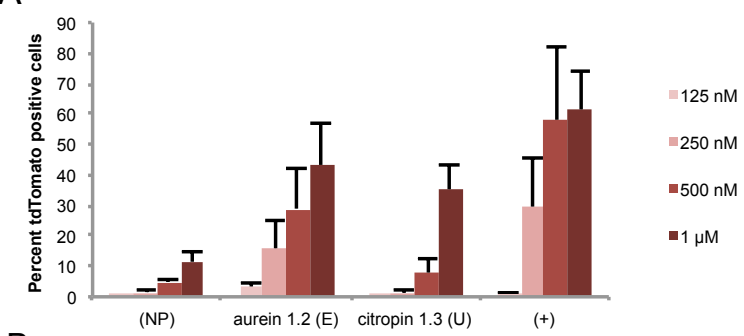

B

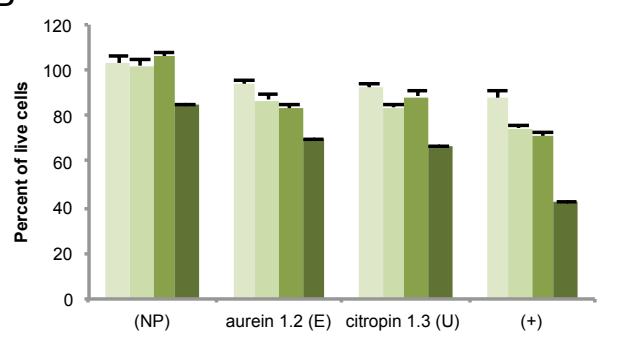

Figure 3. Efficacy and toxicity of recombinant expression fusions of aurein 1.2 ("E") and citropin 1.3 ("U"). (A) Cytosolic Cre delivery results in recombination and tdTomato expression. The percentage of tdTomato positive cells was determined by flow cytometry. Protein fusions were delivered at $125 \mathrm{nM}, 250 \mathrm{nM}, 500 \mathrm{nM}$, and $1 \mu \mathrm{M}$. (B) Toxicity of aurein 1.2 and citropin 1.3 as determined by CellTiterGlo (Promega) assay. Protein fusions were delivered at $125 \mathrm{nM}, 250 \mathrm{nM}$, $500 \mathrm{nM}$, and $1 \mu \mathrm{M}$. The labeled concentration of $+36 \mathrm{GFP}-\mathrm{Cre}$ was used as the no peptide control (NP), and addition of $100 \mu \mathrm{M}$ chloroquine was used as the positive control $(+)$. Cells were treated with 250 $\mathrm{nM}$ protein for $4 \mathrm{~h}$ in serum-free media. Cells were washed and supplanted with full DMEM and incubated for $48 \mathrm{~h}$. Error bars represent the standard deviation of three independent biological replicates.

Next, we evaluated the toxicity of each fusion protein at a range of concentrations ( $125 \mathrm{nM}$ to $1 \mu \mathrm{M}$ ) using an ATP-dependent cell viability assay at $48 \mathrm{~h}$ after treatment. For $+36 \mathrm{GFP}-\mathrm{Cre}$, we observed no cellular toxicity up to $1 \mu \mathrm{M}$ treatment, which resulted in $85 \%$ viable cells. Cells treated with $250 \mathrm{nM}$ recombinant aurein 1.2-+36 GFP-Cre and citropin 1.3-+36 GFP-Cre displayed 87\% and $84 \%$ viability, respectively. Applying $1 \mu \mathrm{M}$ treatments decreased cell viability to $70 \%$ and $66 \%$, respectively (Figure $3 \mathrm{~B}$ ). In light of its activity and low cytotoxicity at $250 \mathrm{nM}$, we characterized in depth the ability of aurein 1.2 to enhance cytosolic protein delivery.

Site-directed mutagenesis of aurein 1.2. Aurein 1.2 (GLFDIIKKIAESF) is a potent AMP excreted from the Australian tree frog, Litoria aurea $^{30}$. Interestingly, citropin 1.3

(GLFDIIKKVASVIGGL) is a closely related peptide and is excreted from a different Australian tree frog, Litoria citropa ${ }^{31}$. While the properties of aurein 1.2 have been investigated for its anti-bacterial and anti-tumorogenic abilities ${ }^{30}$, its ability to enhance endosomal escape or macromolecule delivery has not been previously reported. The free peptide is thought to adopt an amphipathic alpha helical structure in solution, but the length of the helix is too short to span a lipid bilayer ${ }^{32}$. Therefore it has been theorized that aurein 1.2 disrupts membranes through a "carpet mechanism" in which peptides bind to the membrane surface in a manner that allows hydrophobic residues to interact with lipid tails and hydrophilic residues to interact with polar lipid head groups ${ }^{33}$. Above a critical concentration, the peptides are thought to alter the curvature of the membrane enough to break apart the compartment.

Table 2. Site-directed mutagenesis of aurein 1.2

\begin{tabular}{|c|c|}
\hline Label & Sequence \\
\hline Aurein 1.2 & GLFDIIKKIAESF \\
\hline G1A & ALFDIIKKIAESF \\
\hline L2A & GAFDIIKKIAESF \\
\hline F3A & GLADIIKKIAESF \\
\hline $\mathrm{D} 4 \mathrm{~A}$ & GLFAIIKKIAESF \\
\hline $\mathrm{I} 5 \mathrm{~A}$ & GLFDAIIKKIAESF \\
\hline I6A & GLFDIAKKIAESF \\
\hline K7A & GLFDIIAKIAESF \\
\hline K8A & GLFDIIKAIAESF \\
\hline I9A & GLFDIIKKAAAESF \\
\hline E11A & GLFDIIKKIAASF \\
\hline S12A & GLFDIIKKIAEAFF \\
\hline F13A & GLFDIIKKIAESA \\
\hline $\mathrm{K} 7 \mathrm{H}$ & GLFDIIHKIAESF \\
\hline $\mathrm{K} 8 \mathrm{H}$ & GLFDIIKHIAESF \\
\hline $\mathrm{E} 11 \mathrm{H}$ & GLFDIIKKIA $\underline{H S F}$ \\
\hline K7R & GLFDIIRKIAESF \\
\hline K8R & GLFDIIKRIAESF \\
\hline E11R & GLFDIIKKIARSF \\
\hline E11D & GLFDIIKKIADSF \\
\hline
\end{tabular}

An alanine scan was performed on aurein 1.2 to determine positions that tolerate mutation. Charged amino acids at tolerant positions were then replaced with histidines or other charged amino acids in an attempt to increase endosomal escape efficiency. All constructs were expressed as recombinant fusion proteins with +36 GFP-Cre.

To identify the residues involved in enhancing non-endosomal protein delivery, we performed an alanine scan of the 13 amino acid positions of aurein 1.2 by cloning, expressing, and purifying each alanine mutant of aurein 1.2-+36 GFP-Cre. The resulting fusion proteins were assayed in BSR.LNL.tdTomato reporter cells as described above (Table 2 ). Seven positions were moderately to highly intolerant of alanine substitution. Six positions retained $>70 \%$ of the activity of unmutated aurein 1.2-+36 GFP-Cre (Figure 4A). At each of these tolerant positions, which included three positions with charged residues (K7, K8, and E11 from Table 2), we generated additional mutations in an effort to improve activity. In total, 19 mutants of aurein 1.2 were generated and tested using the Cre recombination assay. Two of the aurein variants, K8R and S12A, exhibited potentially improved overall recombination efficiency but also increased toxicity at $250 \mathrm{nM}$ (Figure 4B). Given this increase in toxicity, we decided to focus on the original peptide, aurein 1.2 , and proceeded to characterize its potency through a series of complementary secondary assays. 
A

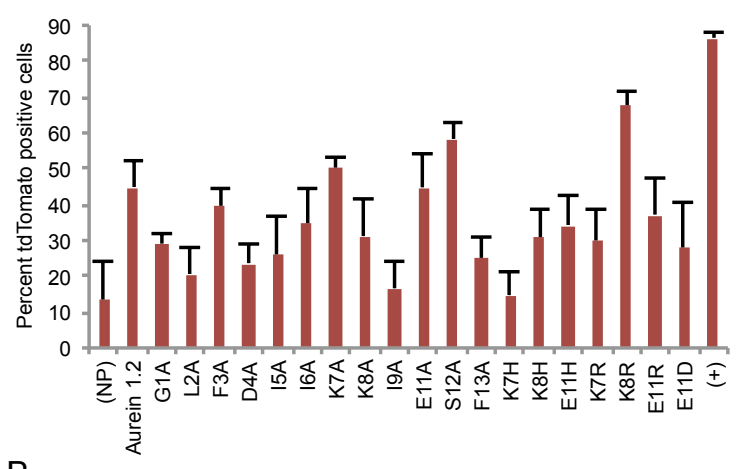

B

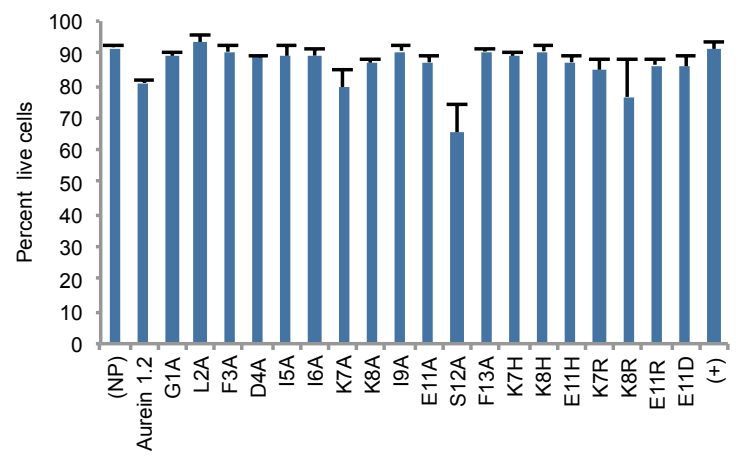

Figure 4. Activity and cytotoxicity of aurein 1.2 variants fused to +36 GFP-Cre(A) The percentage of tdTomato positive cells was determined by flow cytometry. (B) Toxicity as determined by CellTiterGlo (Promega) assay. For (b) and (c), $250 \mathrm{nM}+36 \mathrm{GFP}-\mathrm{Cre}$ was used as the no peptide control (NP), and addition of $100 \mu \mathrm{M}$ chloroquine was used as the positive control $(+)$. Cells were treated with $250 \mathrm{nM}$ protein for $4 \mathrm{~h}$ in serum-free DMEM. Cells were washed and supplanted with full DMEM and incubated for $48 \mathrm{~h}$.

Independent assays of endosomal escape. Although endosomal escape is widely considered to be the major bottleneck of cationic protein delivery ${ }^{34}$, few assays quantify the ability of proteins to escape endosomes on a single-cell basis. To quantify cytosolic delivery of supercharged proteins in individual cells, we applied a glucocorticoid receptor (GR) translocationassay ${ }^{35}$ described by Schepartz and colleagues ${ }^{9,36}$. In untreated HeLa cells expressing mCherry-labeled GR (GR-mCherry), the GR distributes nearly uniformly throughout the cell interior, resulting in a nuclear-to-cytoplasm translocation ratio (TR) of 1.17 (Figure 5A and $5 \mathrm{~B})$. Upon treatment with the cell-permeable glucocorticoid dexamethasone-21-thiopropionic acid (SDex) at a concentration of $1 \mu \mathrm{M}$ for $30 \mathrm{~min}$, GR-mCherry relocates almost exclusively to the nucleus, resulting in a TR of 3.77 (Figure 5A and 5B).
A
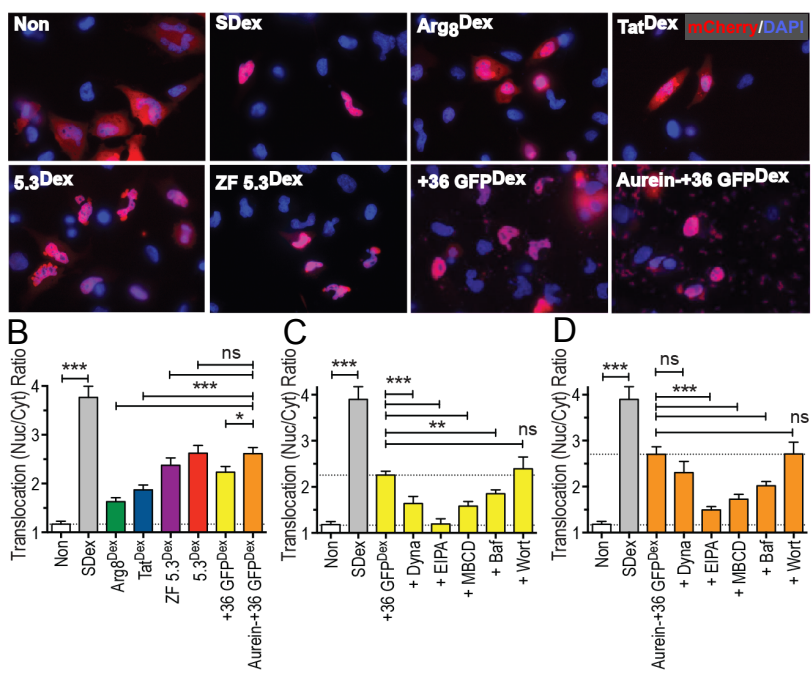

Figure 5. Investigating the ability of +36 GFP and aurein $1.2-+36$ GFP dexamethasone-conjugates to reach the cytosol and activate GR translocation. (A) Images of HeLa cells expressing GR-mCherry treated in the presence and absence of $1 \mu \mathrm{M}$ dexamethasone (Dex)-protein conjugates for $30 \mathrm{~min}$ at $37^{\circ} \mathrm{C}$. (B) Nuclear-to-cytosol GR-mCherry fluorescence ratios (translocation ratios) of respective Dex-protein conjugates determined using CellProfiler ${ }^{\circ}$. (C) GR-mCherry translocation ratios resulting from cells treated in the presence and absence of $+36 \mathrm{GFP}^{\mathrm{Dex}}$ and endocytic inhibitors. (D) GR-mCherry translocation ratios resulting from cells treated in the presence and absence of aurein $1.2-+36 \mathrm{GFP}^{\mathrm{Dex}}$ and endocytic inhibitors. Statistical significance is measured by $\mathrm{P}$-value. $\mathrm{ns}=\mathrm{P}>0.05,{ }^{*}=\mathrm{P} \leq 0.05,{ }^{* *}=\mathrm{P} \leq 0.01,{ }^{* * *}=\mathrm{P} \leq$ 0.001 .

We generated dexamethasone conjugates of $+36 \mathrm{GFP}(+36$ $\mathrm{GFP}^{\mathrm{Dex}}$ ) and aurein $1.2-+36 \mathrm{GFP}$ (aurein $1.2-+36 \mathrm{GFP}^{\mathrm{Dex}}$ ) via sortase-mediated conjugation (Supporting Information Figure S4). Conjugated to these proteins, SDex is no longer cell permeable and cannot activate the GR for nuclear translocation unless the proteinSDex conjugate can access the cytosol. Treatment of HeLa cells expressing GR-mCherry with $1 \mu \mathrm{M}$ aurein $1.2-+36 \mathrm{GFP}^{\mathrm{Dex}}$ for 30 min resulted in a TR of 2.62 , which was significantly greater $(p<$ $0.05)$ than that of $+36 \mathrm{GFP}^{\mathrm{Dex}}(\mathrm{TR}=2.23)$. As positive controls, we treated these cells with canonical cell permeable peptides ( $\mathrm{Tat}{ }^{\mathrm{Dex}}$ and $\mathrm{Arg}_{8}{ }^{\mathrm{Dex}}$ ) and miniature proteins containing a penta-Arg motif that reach the cytosol intact, with efficiencies exceeding $50 \%\left(5.3^{\text {Dex }}\right.$ and ZF $\left.5.3^{\text {Dex }}\right)^{37}$. Aurein $1.2-+36 \mathrm{GFP}^{\text {Dex }}(\mathrm{TR}=2.62)$, activated significantly greater levels of GR-mCherry translocation $(p<0.001)$ than $\mathrm{Tat}^{\mathrm{Dex}}(\mathrm{TR}=1.87)$ and $\mathrm{Arg}^{\mathrm{Dex}}(\mathrm{TR}=1.63)$ and similar levels evoked by miniature proteins $5.3^{\text {Dex }}(\mathrm{TR}=2.62)$ and ZF $5.3^{\text {Dex }}(\mathrm{TR}$ $=2.38)$ (Figure 5A and 5B). Taken together, these results suggest that aurein $1.2-+36 \mathrm{GFP}^{\mathrm{Dex}}$ exhibits an improved ability to access the cytoplasm over $+36 \mathrm{GFP}^{\text {Dex }}$ and canonical cell permeable peptides.

As an additional, independent assay of non-endosomal protein delivery, we tested the ability of aurein 1.2 to enhance the nonendosomal delivery of an evolved biotin ligase (BirA) enzyme developed by Ting and coworkers ${ }^{38}$. BirA catalyzes the biotinylation of a 15-amino acid acceptor peptide (AP). We transfected a mCherry-AP fusion plasmid into HeLa cells. Biotinylation of mCherry can only occur in the presence of cytosolic BirA. To assess the non-endosomal delivery of +36 GFP-BirA protein, 
mCherry-AP biotinylation was quantified by Western blot using fluorophore-labeled streptavidin and normalized to the mCherry signal (Supporting Information Figure S5A). Treatment with 250 $\mathrm{nM}$ aurein $1.2-+36$ GFP-BirA resulted in a $50 \%$ increase in biotinylation signal compared with $250 \mathrm{nM}$ of $+36 \mathrm{GFP}-\mathrm{BirA}$ alone (Supporting Information Figure S5B). We also observed a dosedependent increase in AP-biotinylation across treatment concentrations $(250 \mathrm{nM}, 500 \mathrm{nM}$, and $1 \mu \mathrm{M})$ for both aurein $1.2-(+36$ GFP)-BirA and unfused +36 GFP-BirA constructs. These results are consistent with the results of the GR translocation assay, and further suggest that aurein 1.2 enhances the endosomal escape of superpositively charged proteins.

In order to directly quantify the increase in non-endosomal delivery resulting from aurein 1.2, we performed a cytosolic fractionation experiment to calculate the cytosolic concentrations of delivered protein. HeLa cells were treated with +36 GFP or aurein 1.2$+36 \mathrm{GFP}$ at $250 \mathrm{nM}, 500 \mathrm{nM}$, and $1 \mu \mathrm{M}$. After $30 \mathrm{~min}$ of treatment, cells were washed, homogenized, and fractionated by ultracentrifugation. The cytosolic concentration of delivered protein was calculated from the GFP fluorescence of the cytosolic fraction together with a standard curve relating fluorescence to known concentrations of +36 GFP and aurein 1.2-+36 GFP added to cytosolic extract (Supporting Information Figures S6B and 6C). At $250 \mathrm{nM}$, treatment with aurein 1.2-+36 GFP resulted in $\sim 5$-fold more delivered cytosolic protein than treatment with +36 GFP alone (Supporting Information Figure S6A). This difference decreased with increasing protein concentration, likely due to the influence of alternate uptake pathways or delivery bottlenecks at high protein concentrations. In contrast, the total amount of aurein $1.2-+36$ GFP versus +36 GFP uptaken by cells was similar, with aurein 1.2+36 GFP showing 1.3-fold higher total cellular uptake at $250 \mathrm{nM}$. These results directly demonstrate that aurein 1.2 increases the cytosolic concentration of cationic proteins that enter cells predominantly through endosomes, ${ }^{14,18}$ and are consistent with the above findings that aurein 1.2 has the greatest effect on enhancing non-endosomal delivery at $\sim 250 \mathrm{nM}$ (Figure $3 \mathrm{~A}$ ).

Effect of endocytic inhibitors on +36 GFP and aurein 1.2+36 GFP delivery. We previously reported that endocytosis plays a key role in the cytosolic delivery of superpositively charged proteins ${ }^{18}$. To probe the role of endocytosis in the delivery of supercharged proteins with or without aurein 1.2, we treated cells expressing GR-mCherry with either $+36 \mathrm{GFP}^{\mathrm{Dex}}$ or aurein $1.2-+36$ $\mathrm{GFP}^{\mathrm{Dex}}$ in the presence of known endocytic inhibitors. The cortical actin remodeling inhibitor $\mathrm{N}$-ethyl-isopropyl amiloride (EIPA), the cholesterol-sequestering agent methyl- $\beta$-cyclodextrin (MBCD), and the endosomal vesicular ATPase inhibitor bafilomycin (Baf) all strongly reduced the ability of both proteins to stimulate GRmCherry translocation. Blocking maturation of Rab5 $5^{+}$vesicles by treatment with the phosphatidylinositol 3-kinase inhibitor wortmannin (Wort) did not influence reporter translocation of either $+36 \mathrm{GFP}^{\text {Dex }}$ or aurein $1.2-+36 \mathrm{GFP}^{\text {Dex }}$ (Figure 5C and 5D). In contrast, treatment with the small-molecule dynamin II inhibitor Dynasore (Dyna) significantly suppressed the ability of $+36 \mathrm{GFP}^{\text {Dex }}$ to stimulate GR-mCherry translocation $(\mathrm{TR}=1.64)$ (Figure $5 \mathrm{C}$ ) but had little influence on the cytosolic delivery of aurein 1.2-+36 $\mathrm{GFP}^{\mathrm{Dex}}(\mathrm{TR}=2.30)$ (Figure 5D). Taken together, these results suggest that active endocytosis is required for uptake of +36 GFP and aurein 1.2-+36GFP into the cell interior, and that the two proteins may traffic differently into the cell interior.
Aurein 1.2 can greatly increase protein delivery efficiency in vivo. To evaluate the ability of aurein 1.2 to increase the efficacy of cationic protein delivery in vivo, we delivered proteins to the inner ear of Cre reporter transgenic mice that express tdTomato upon Cre-mediated recombination. This animal model was chosen due to its confined injection volume, the presence of wellcharacterized cell types, and the existence of genetic deafness models that would facilitate future studies of protein delivery to treat hearing loss. We previously showed that +36 GFP-Cre alone can be delivered to mouse retina, ${ }^{15}$ albeit resulting in only modest levels of recombination consistent with inefficient endosomal escape.

Anesthetized postnatal day 2 (P2) mice were injected with 0.4 $\mu \mathrm{L}$ of $50 \mu \mathrm{M}+36 \mathrm{GFP}-\mathrm{Cre}$ or aurein 1.2-+36 GFP-Cre solutions in the scala media to access the cochlear cells. Five days after injection, the cochleas were harvested for immunolabeling of inner ear cell markers and imaging for tdTomato florescence (Figure 6A). We evaluated both the hair cells (Myo7a+) and supporting cells (Myo7a-) for td Tomato signal. The total number of hair cells and supporting cells (by DAPI labeling) in the sensory epithelium (SE) was used to determine the relative toxicity of aurein $1.2-+36 \mathrm{GFP}-$ Cre to the baseline treatment of +36 GFP-Cre (Figure 6A). Overall, an average of $96 \%, 92 \%$ and $66 \%$ of cochlear cells survived aurein 1.2-+36 GFP-Cre treatment as compared to +36 GFP-Cre treatment in the apex, middle, and base tissue samples, respectively (Figure 6A) . +36 GFP-Cre treatment resulted in low levels of recombination only in inner hair cells (IHC) of the apex of the cochlea $(4.4 \%)$ but not in the middle or base of the cochlear hair cells or any cochlear supporting cells. In contrast, treatment with aurein 1.2-+36 GFP-Cre resulted in very high Cre-mediated recombination levels throughout the apex, middle, and base samples of outer hair cells (OHC) (96\%, 91\%, and 69\%, respectively), inner hair cells $(100 \%, 94 \%$, and $70 \%$, respectively), as well as supporting cells (arrows) (Figure 6A and 6C). 


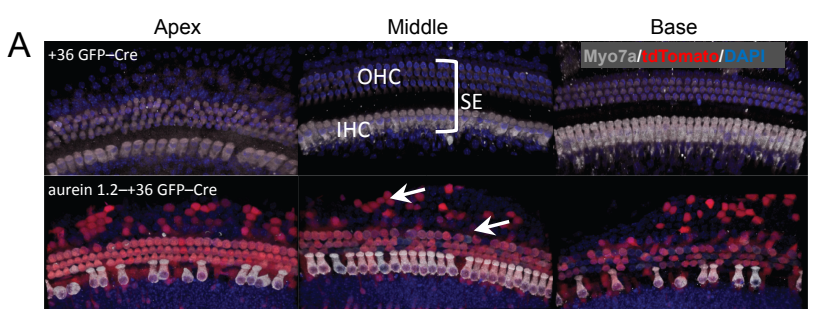

B
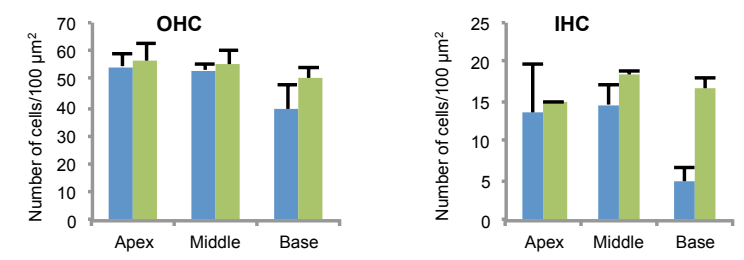

"aurein 1.2-+36 GFP-Cre $\quad+36$ GFP-Cre

C
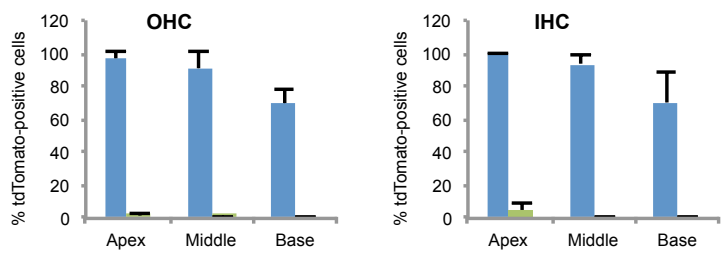

=aurein 1.2-+36 GFP-Cre $\quad=+36$ GFP-Cre

Figure 6. In vivo protein delivery of Cre recombinase into mouse neonatal cochleas. $0.4 \mu \mathrm{L}$ of $50 \mu \mathrm{M}+36 \mathrm{GFP}-\mathrm{Cre}$ or aurein 1.2-+36 GFPCre were injected into the scala media. (A) Five days after injection, cochlea were harvested. Inner hair cells (IHC), outer hair cells (OHC) and supporting cells in the sensory epithelium (SE) were imaged for the presence of $\mathrm{tdT}$ Tomato, which is only expressed following Cremediated recombination. Hair cells were labeled with antibodies against the hair-cell marker Myo7a. Gray/white $=$ Myo7a, Red $=$ tdTomato, Blue = DAPI. (B) To evaluate cytotoxicity, the number of outer hair cells and inner hair cells were measured by counting DAPIstained cells (C) The percentage of tdTomato positive cells, reflecting successful delivery of functional Cre recombinase, was determined by fluorescence imaging.

The observed levels of recombination in the inner hair cells from aurein 1.2-+36 GFP-Cre are comparable to that of adenoassociated virus type 1 (AAV1) gene transfection ${ }^{39}$. For outer hair cells, we have previously shown similar levels of recombination using liposome-mediated delivery of supernegatively-charged GFP-Cre ${ }^{40}$. The aurein 1.2-+36 GFP-Cre delivery system is the only method that showed significant recombination levels in both inner and outer hair cells ${ }^{39,41}$, and does not require any virus or other molecules beyond a single polypeptide. Significantly, aurein $1.2-+36$ GFP-Cre also extended delivered recombinase activity to additional cochlear supporting cells. These results suggest aurein 1.2-+36 GFP-Cre delivery system to be a promising method for in vivo protein delivery into both hair cells and supporting cells of the inner ear ${ }^{42}$.

\section{CONCLUSION}

We discovered a 13-residue peptide, aurein 1.2, that can increase the efficiency of non-endosomal protein delivery by screening a panel of known membrane-active peptides. The results from a small screen of 22 peptides are consistent with our hypothesis that

some peptides can selectively disrupt the endosomal membrane without disrupting the mammalian cell membrane. The effectiveness of aurein 1.2 is highly dependent on its sequence, as several other closely related peptides did not enhance protein delivery (Tables 1 and 2). Subtle differences in amino acid composition led to dramatic changes in membrane activity among peptides tested, highlighting the difficulty of rationally designing peptides that enhance non-endosomal delivery. Moreover, the lack of correspondence between peptide cationic charge and non-endosomal delivery efficiency suggests that aurein 1.2 does not enhance nonendosomal delivery simply by promoting endocytosis. While none of the tested variants of aurein 1.2 substantially outperformed the original peptide, we identified several amino acids that could be altered without loss of activity. These findings also provide a starting point for further optimization to discover next-generation endosomolytic peptides with improved efficacy and reduced toxicity.

Four independent assays for non-endosomal protein delivery (Cre recombination, GR translocation, BirA activity on a cytoplasmic peptide, and cytosolic fractionation), together with the peptide mutational studies described above, collectively suggest that aurein 1.2-fusion enhances endosomal escape of superpositively charged proteins. Moreover, these assays collectively demonstrated the ability of aurein 1.2 to mediate the non-endosomal delivery of +36 GFP fused to different proteins (or small molecules), suggesting that aurein 1.2 facilities endosomal escape in a manner that is at least somewhat cargo-independent.

The in vivo protein delivery experiments described above revealed dramatic increases in non-endosomal functional Cre recombinase delivery into the diverse inner ear cell types including hair cells and supporting cells of live mice upon fusion with aurein 1.2. Indeed, aurein 1.2-fused +36 GFP-Cre construct resulted in highly efficient recombination levels across the main cochlear sensory epithelial cell classes studied in this work, all but one of which were unaffected by +36 GFP-Cre treatment. Taken together, these results suggest that aurein 1.2 is a 13-residue, potent, genetically encodable, endosome escape-enhancing peptide that can greatly increase the efficiency of non-endosomal cationic protein delivery in vitro and in vivo without requiring the use of additional components beyond the protein of interest.

\section{EXPERIMENTAL SECTION}

Construction of expression plasmids. Sequences of all constructs used in this paper are listed in the Supporting Information. All protein constructs were generated from previously reported plasmids for protein of interest cloned into a pET29a expression plasmid $^{43}$. All plasmid constructs generated in this work will be deposited with Addgene.

Expression and purification of proteins. E. coli BL21 STAR (DE3) competent cells (Life Technologies) were transformed with pET29a expression plasmids. Colonies from the resulting expression strain was directly inoculated in $1 \mathrm{~L}$ of Luria-Bertani (LB) broth containing $100 \mu \mathrm{g} / \mathrm{mL}$ of ampicillin at $37^{\circ} \mathrm{C}$ to $\mathrm{OD}_{600}=\sim 1.0$. Isopropyl $\beta$-D-1- thiogalactopyranoside (IPTG) was added at 0.5 $\mathrm{mM}$ to induce expression and the culture was moved to $20^{\circ} \mathrm{C}$. After $\sim 16 \mathrm{~h}$, the cells were collected by centrifugation at $6,000 \mathrm{~g}$ and resuspended in lysis buffer (Phosphate buffered saline (PBS) with $1 \mathrm{M} \mathrm{NaCl}$ ). The cells were lysed by sonication ( $1 \mathrm{sec}$ pulse-on, $1 \mathrm{sec}$ pulse-off for $6 \mathrm{~min}$, twice, at $6 \mathrm{~W}$ output) and the soluble lysate was obtained by centrifugation at $10,000 \mathrm{~g}$ for $30 \mathrm{~min}$. 
The cell lysate was incubated with His-Pur nickel-nitriloacetic acid (Ni-NTA) resin (Thermo Scientific) at $4{ }^{\circ} \mathrm{C}$ for $45 \mathrm{~min}$ to capture His-tagged protein. The resin was transferred to a $20-\mathrm{mL}$ column and washed with 20 column volumes of lysis buffer plus 50 $\mathrm{mM}$ imidazole. Protein was eluted in lysis buffer with $500 \mathrm{mM}$ imidazole, and concentrated by Amicon ultra centrifugal filter (Millipore, $30-\mathrm{kDa}$ molecular weight cut-off) to $\sim 50 \mathrm{mg} / \mathrm{mL}$. The eluent was injected into a $1 \mathrm{~mL}$ HiTrap SP HP column (GE Healthcare) after dilution into PBS (5-fold). Protein was eluted with $\mathrm{PBS}$ containing a linear $\mathrm{NaCl}$ gradient from $0.1 \mathrm{M}$ to $1 \mathrm{M}$ over five column volumes. The eluted fractions containing protein were concentrated to $50 \mu \mathrm{M}$ as quantified by absorbance at $488 \mathrm{~nm}$ assuming an extinction coefficient of $8.33 \times 10^{4} \mathrm{M}^{-1} \mathrm{~cm}^{-1}$ as previously determined ${ }^{14}$, snap-frozen in liquid nitrogen, and stored in aliquots at $-80^{\circ} \mathrm{C}$.

Cell Culture. All cells were cultured in Dulbecco's modification of Eagle's medium (DMEM w/glutamine, Gibco) with 10\% fetal bovine serum (FBS, Gibco), 5 I.U. penicillin, and $5 \mathrm{~g} / \mathrm{mL}$ streptamycin. All cells were cultured at $37{ }^{\circ} \mathrm{C}$ with $5 \% \mathrm{CO}_{2}$.

Peptide synthesis. Peptides were ordered from ChinaPeptides Co., LTD, each $4 \mathrm{mg}$, purity $>90 \%$. HPLC and MALDI data were provided with lyophilized peptides. Peptides were resuspeneded in DMSO to a final concentration of $10 \mathrm{mM}$.

Sortase conjugation. All reactions were performed in $100 \mathrm{mM}$ Tris buffer ( $\mathrm{pH} 7.5)$ with $5 \mathrm{mM} \mathrm{CaCl}_{2}$ and $1 \mathrm{M} \mathrm{NaCl}$. For peptide conjugation to the $\mathrm{N}$-terminus of GGG-+36-GFP , $20 \mu \mathrm{M}$ of protein with $\mathrm{N}$-terminal Gly-Gly-Gly was incubated with $400 \mu \mathrm{M}$ of peptide with C-terminal LPETGG and $1 \mu \mathrm{M}$ eSrtA for $2 \mathrm{~h}$ at room temperature in a $50 \mu \mathrm{L}$ reaction. The unreacted peptides were removed through spin filtration with an Amicon Ultra-0.5 Centrifugal Filter Unit (Millipore, 30-kDa molecular weight cut-off). The reaction mixture was washed twice with $500 \mu \mathrm{L}$ of buffer each time to a final concentration of $50 \mu \mathrm{L}$. Conjugation efficiency was determined through LC-MS (Agilent 6220 ESI-TOF) using protein deconvolution through MaxEnt (Waters) by comparing relative peak intensities.

For conjugation of GGGK ${ }^{\text {Dex }}$ to +36-GFP-LPETG-His 6 , 10 $\mu \mathrm{M}$ of protein was incubated with $400 \mu \mathrm{M}$ of peptide and $2 \mu \mathrm{M}$ eSrtA at room temperature. The reaction was quenched with 10 $\mathrm{mM}$ ethylenediaminetetraacetic acid (EDTA) after $2 \mathrm{~h}$. For aurein 1.2-+36-GFP-LPETG-His 6 , a N-terminal His ${ }_{6}$-ENLYFQ was added to prevent sortase reaction with the $\mathrm{N}$-terminal glycine of aurein 1.2. The $\mathrm{N}$-terminal tag was removed with $200 \mu \mathrm{M}$ TEV protease at $4{ }^{\circ} \mathrm{C}$ for $16 \mathrm{~h}$ to release the native $\mathrm{N}$-terminal sequence of aurein 1.2-+36-GFP. Successful conjugation of GGGK ${ }^{\text {Dex }}$ removes the $\mathrm{C}$-terminal $\mathrm{His}_{6}$ tag and allows for purification through reverse Ni-NTA column. Unreacted protein binds to the Ni-NTA, and the unbound protein was collected and concentrated as described above.

Plasmid transfection. Plasmid DNA was transfected using Lipofectamine 2000 (Life Technologies) according the manufacturer's protocol.

\section{Synthesis of Dexamethasone-21 Thiopropionic Acid} (SDex). Synthesis of dexamethasone-21-mesylate was performed as previously described. ${ }^{44,45} 2 \mathrm{~g}$ of dexamethasone stirring in $38 \mathrm{~mL}$ anhydrous pyridine under nitrogen was reacted with $467.2 \mathrm{~m}$ gmethanesulfonyl chloride ( 1.2 eq.) on ice for $1 \mathrm{~h}$, after which another 311 methanesulfonmethanesulfonyl chloride was added and allowed to react overnight (16h) on ice. Next, the reaction was added to $800 \mathrm{~mL}$ of ice water and Dexamethasone-21-Mesylate (Dex-21-OMs) formed a white precipitate. The slurry was filtered and the precipitate washed with $800 \mathrm{~mL}$ of ice water, dried under high vacuum overnight and quantified by LC-MS (m/z 471.19 Da, $83 \%$ yield).

Dexamethasone-21-thiopopionic acid (SDex) was prepared as previously described. ${ }^{46} 2.05 \mathrm{~g}$ of Dex-21-OMs was added to $2 \mathrm{eq}$. thiopropionic acid and 4 eq. triethylamine stirring in anhydrous acetone at room temperature overnight. The following morning, the reaction was added to $800 \mathrm{~mL}$ of ice water and acidified with 1 $\mathrm{N} \mathrm{HCl}$ until SDex, visible as an off-white solid, precipitation was complete. The mixture was filtered, washed with $800 \mathrm{~mL}$ ice cold water acidified to $\mathrm{pH} 1$ with $\mathrm{HCl}$, dried under high vacuum overnight and analyzed by LC-MS (m/z 481.21 Da, 63\% yield) (Supporting Figure 7).

Synthesis and Purification of GGGK ${ }^{\text {Dex }}$. GGGK ${ }^{\text {Dex }}$ was synthesized on Fmoc-Lys (Mtt)-Wang resin (BACHEM, D-2565) using microwave acceleratin (MARS, CEM). Coupling reactions were performed using 5 equivalents of Fmoc-Gly-OH (Novabiochem, 29022-11-5), 5 equivalents of PyClock (Novabiochem, 893413-42-8) and 10 equivalents of diisopropylethylamine (DIEA) in N-methylpyrrolidone (NMP). Fmoc groups were removed using $25 \%$ piperidine in NMP (efficiency quantified; $\varepsilon_{299}=6234 \mathrm{M}^{-1} \mathrm{~cm}^{-1}$ in acetonitrile) and Mtt groups were removed by incubating the Fmoc-GGGK(Mtt)-resin with $2 \%$ trifluoroacetic acid (TFA) in dichloromethane (DCM) for $20 \mathrm{~min}$, after which the resin was washed with $2 \%$ TFA in DCM until the characteristic yellow color emitting from the Mttcation subsided. After Mtt removal, SDex-COOH (Dex-21-thiopropinonic acid ${ }^{35}$ ) was coupled to the $\mathrm{N} \varepsilon$ of the lysine side-chain by incubating the Fmoc-GGGKresin with 2.5 eq. SDex-COOH, 2.5 eq. HATU, 2.5 eq. HOAt, 5 eq. DIEA and 5 eq. 2,6-lutidine in $2.5 \mathrm{~mL}$ NMP overnight, at room temperature, on an orbital shaker. After SDex-labeling, Fmoc$\mathrm{GGGK}^{\mathrm{Dex}}$-resin was washed thoroughly with NMP and DCM, the $\mathrm{N}$-terminal Fmoc was removed using $25 \%$ piperidine in NMP, and crude peptides were dissociated from the resin by incubating the GGGK $^{\text {Dex }}$-resin in a cleavage cocktail composed of $81.5 \%$ trifluoroacetic acid (TFA), $5 \%$ thioanisole, $5 \%$ phenol, $5 \%$ water, $2.5 \%$ ethanedithiol and $1 \%$ triisopropylsilane for $30 \mathrm{~min}$ at $38^{\circ} \mathrm{C}$. Crude peptides were precipitated in $40 \mathrm{~mL}$ cold diethyl ether, resuspended in water, lyophilized and purified via reverse phase high-pressure liquid chromatography (HPLC) using a linear gradient of acetonitrile and water with $0.1 \%$ TFA across a C18 (VYDAC, 250mm x 10 $\mathrm{mm}$ ID) column. Purified peptides were lyophilized and stored at $4{ }^{\circ} \mathrm{C}$. Polypeptide identity was confirmed by mass spectrometry on a Waters QToF LC-MS, and purity was measured by analytical reverse-phase HPLC (Shimadzu Instruments) using a C18 column (Poroshell 120 SB-C18, $2.7 \mu \mathrm{m}, 100 \mathrm{~mm} \times 3$ mm ID, Agilent).

Image processing for primary screen. BSR.LNL.tdTomato cells were plated at 10,000 cells per well in black 384-well plates (Aurora Biotechnologies). Cells were treated with Cre fusion proteins diluted in serum-free DMEM $24 \mathrm{~h}$ after plating and incubated for $4 \mathrm{~h}$ at $37^{\circ} \mathrm{C}$. Following incubation, the cells were washed three times with PBS $+20 \mathrm{U} / \mathrm{mL}$ heparin. The cells were incubated a further $48 \mathrm{~h}$ in serum-containing media. Cells were fixed in 3\% paraformaldehyde and stained with Hoescht 33342 nuclear dye. Images were acquired on an ImageXpress Micro automated microscope (Molecular Devices) using a $4 \times$ objective (binning 2, gain 2 ), with laser- and image-based focusing (offset $-130 \mu \mathrm{m}$, range \pm 50 
$\mu \mathrm{m}$, step $25 \mu \mathrm{m})$. Images were exposed for $10 \mathrm{~ms}$ in the DAPI channel (Hoechst) and $500 \mathrm{~ms}$ in the dsRed channel (tdTomato). Image analysis was performed using the cell-scoring module of MetaXpress software (Molecular Devices). All nuclei were detected with a minimum width of 1 pixel, maximum width of 3 pixels, and an intensity of 200 gray levels above background. Positive cells were evaluated for uniform signal in the dsRed channel (minimum width of 5 pixels, maximum width of 30 pixels, intensity $>200$ gray levels above background, $10 \mu \mathrm{m}$ minimum stained area). In total, nine images were captured and analyzed per well, and 16 wells were treated with the same fusion protein. The primary screen was completed in biological triplicate.

Cre delivery assay. Uptake and delivery assays for Cre fusion proteins were performed as previously described ${ }^{15}$. Briefly, proteins were diluted in serum-free DMEM and incubated on the cells in 48-well plates for $4 \mathrm{~h}$ at $37^{\circ} \mathrm{C}$. Following incubation, the cells were washed three times with PBS $+20 \mathrm{U} / \mathrm{mL}$ heparin. The cells were incubated a further $48 \mathrm{~h}$ in serum-containing media prior to trypsinization and analysis by flow cytometry. All flow cytometry were carried out on a BD Fortessa flow cytometer (Becton-Dickinson) using $530 / 30 \mathrm{~nm}$ and $610 / 20 \mathrm{~nm}$ filter sets. Toxicity for aurein 1.2 and citropin 1.3 validation assays was determined using CellTiterGlo assay (Promega) in 96-well plates following manufacturer protocol. Toxicity for alanine scan mutational analysis was determined with LIVE/DEAD fixable far-red dead cell stain (Life Technologies) with $635 \mathrm{~nm}$ laser and 670/30 nm filter.

GR-mCherry translocation assay. One day prior to transfection 10,000 HeLa cells in $200 \mu \mathrm{L}$ of DMEM (10\% FBS, 1x PenStrep) were plated into single wells of a 96-well MatriCal glass bottom microplate (MGB096-1-2-LG-L) and allowed to adhere overnight. The following day, cells were transfected with GRmCherry ${ }^{9}$ using Lipofectamine ${ }^{\circledR} 2000$ technologies. Following transfection, cells were allowed to recover overnight in DMEM (+ $10 \%$ FBS). The following day, cells were treated with dexamethasone (Dex) or $1 \mu \mathrm{M}$ Dex-protein conjugate in the presence or absence of inhibitor diluted into DMEM (without phenol red, $+300 \mathrm{nM}$ Hoescht33342). After $30 \mathrm{~min}$, cells were washed twice with $200 \mu \mathrm{L}$ of HEPES-Krebs-Ringer's (HKR) buffer $(140 \mathrm{mM}$ $\mathrm{NaCl}, 2 \mathrm{mM} \mathrm{KCl}, 1 \mathrm{mM} \mathrm{CaCl}_{2}, 1 \mathrm{mM} \mathrm{MgCl}_{2}$, and $10 \mathrm{mM}$ HEPES at $\mathrm{pH}$ 7.4), after which $100 \mu \mathrm{L}$ of HKR buffer was overlaid onto the cells and images were acquired on a Zeiss Axiovert 200M epifluorescence microscope outfitted with Ziess AxiocammRM camera and an EXFO-Excite series $120 \mathrm{Hg}$ arc lamp. The translocation ratio (the ratio of median GFP intensity in the nuclear and surrounding regions) for individual cells was measured using CellProfiler $^{\otimes}$ as described ${ }^{36}$. To examine the effect of endocytosis inhibitors, HeLa cells were pretreated for $30 \mathrm{~min}$ with DMEM (without phenol red) containing inhibitors $(80 \mu \mathrm{M}$ Dynasore, $5 \mathrm{mM}$ MBCD, $50 \mu \mathrm{M}$ EIPA, $200 \mathrm{nM}$ bafilomycin or $200 \mathrm{nM}$ wortmannin) at $37^{\circ} \mathrm{C}$ for $30 \mathrm{~min}$ before incubation with Dex or Dex-protein conjugates.

BirA translocation assay. One day prior to transfection, 100,000 HeLa cells in $1 \mathrm{~mL}$ of DMEM (10\% FBS, $1 \mathrm{x}$ PenStrep) were plated into single wells of a 12 -well tissue culture plate and allowed to adhere overnight. Cells were transfected with mCherryAP fusion protein using Lipofectamine ${ }^{\otimes} 2000$ technologies according to manufacture guidelines $24 \mathrm{~h}$ before protein treatment. Next day, transfected cells were treated for $1 \mathrm{~h}$ at $37^{\circ} \mathrm{C}$ with $+36 \mathrm{GFP}-$ BirA or aurein 1.2-+36 GFP-BirA diluted in serum-free DMEM at
$250 \mathrm{nM}, 500 \mathrm{nM}$ and $1 \mu \mathrm{M}$ concentrations. $250 \mathrm{nM}+36 \mathrm{GFP}-\mathrm{BirA}$ $+100 \mu \mathrm{M}$ chloroquine was also used as a positive control for endosomal escape. The cells were washed three times with PBS containing heparin to remove excess supercharged proteins that were not internalized. The cells were then treated with $100 \mu \mathrm{L}$ of $10 \mu \mathrm{M}$ biotin and $1 \mathrm{mM}$ ATP in PBS for $10 \mathrm{~min}$. The reaction was quenched with excess $(10 \mu \mathrm{L}$ of $8 \mathrm{mM})$ synthesized AP before cells were trypsinized and lysed. To verify that extracellular BirA was not generating signal during lysis, $1 \mu \mathrm{M}+36 \mathrm{GFP}-\mathrm{BirA}$ or aurein $1.2-$ +36 GFP-BirA was added during the quench step to untreated wells. Cells were lysed with $100 \mu \mathrm{L}$ of trypsin and lysed with QIAshredder columns (Qiagen). $30 \mu \mathrm{L}$ of lysate was loaded onto 4$12 \%$ Bis-Tris Bolt gels in Bolt-MES buffer (Life Technologies) and ran for $20 \mathrm{~min}$ at 200 volts. Gels were transferred to PVDF membrane using iBlot 2 transfer system (Life Technologies). Biotinylation was measured through western blotting using the LI-COR quantitative infrared fluorescent antibodies and the Odyssey Imager detection system. To normalize for transfection and gel loading variables, the ratio of biotin signal to mCherry signal was used for comparison.

Cytosolic fractionation assay. One day prior to fractionation, $4 \times 10^{6} \mathrm{HeLa}$ cells were plated in $20 \mathrm{~mL}$ of DMEM ( $10 \% \mathrm{FBS}, 1 \mathrm{x}$ PenStrep, no phenol red) in $175-\mathrm{cm}^{2}$ culture flasks and allowed to adhere for 15 hours. The following day, the media was removed from each flask and the cells were washed twice with clear DMEM (no FBS, no PenStrep, no phenol red). The media was replaced with $7 \mathrm{~mL}$ of clear DMEM containing +36 GFP or aurein 1.2-+36 GFP at a concentration of $250 \mathrm{nM}, 500 \mathrm{nM}$, or $1 \mu \mathrm{M}$. Several flasks were treated with clear DMEM to be used as negative controls and to generate calibration curves with the cytosolic extracts. The cells were incubated for $30 \mathrm{~min}$ at $37^{\circ} \mathrm{C}, 5 \% \mathrm{CO}_{2}$ after which they were washed three times with PBS. Using a cell-scraper, the cells were suspended in $5 \mathrm{~mL}$ of PBS, transferred into a $15 \mathrm{~mL}$ Falcon tube, and pelleted at $500 \mathrm{~g}$ for $3 \mathrm{~min}$. The cells were resuspended in $1 \mathrm{~mL}$ PBS, counted using an automated cell counter (Auto T4, Cellometer $\left.^{\circledR}\right)$, and pelleted again at $500 \mathrm{~g}$ for $3 \mathrm{~min}$. The cell pellet was resuspended in ice-cold isotonic sucrose $(290 \mathrm{mM}$ sucrose, $10 \mathrm{mM}$ imidazole, pH 7.0 with $1 \mathrm{mM}$ DTT, and cOmplete ${ }^{\mathrm{Tu}}$, EDTA-free protease inhibitor cocktail) and transferred to a glass test tube on ice. The cells were homogenized with an Omni TH homogenizer outfitted with a stainless steel $5 \mathrm{~mm}$ probe for three $30 \mathrm{~s}$ pulses on ice with $30 \mathrm{~s}$ pauses between the pulses. The homogenized cell lysate was sedimented at $350 \mathrm{Kg}$ in an ultracentrifuge (TL-100; Beckman Coulter) for $30 \mathrm{~min}$ at $4{ }^{\circ} \mathrm{C}$ using a TLA 120.2 rotor. The supernatant (cytosolic fraction) was analyzed in a 96-well plate on a fluorescence plate reader (Synergy 2, BioTek, excitation $=485$ $+/-10 \mathrm{~nm}$, emission $=528+/-10 \mathrm{~nm})$. The concentration of the protein conjugate in the cytosol was determined using a standard curve relating fluorescence to known protein concentrations. To generate the standard curve, known concentrations of +36 GFP and aurein $1.2-+36$ GFP between $0.2 \mathrm{nM}$ and $1 \mu \mathrm{M}$ were added to cytosolic extracts of the untreated negative controls. For background subtraction, several wells containing cytosolic extracts from untreated cells were averaged, and this average was subtracted from each well.

Total protein delivery assay. One day prior to the experiment, 100,000 HeLa cells/well were plated in DMEM (10\% FBS, $1 \mathrm{x}$ PenStrep, no phenol red) in 6-well plates and allowed to adhere for 15 hours. The following day, the media was removed from each well and the cells were washed twice with clear DMEM (no FBS, 
no PenStrep, no phenol red). The media was replaced with $1 \mathrm{~mL}$ of clear DMEM containing +36 GFP or aurein $1.2-+36$ GFP at concentrations of $250 \mathrm{nM}, 500 \mathrm{nM}$, or $1 \mu \mathrm{M}$. The cells were incubated for $30 \mathrm{~min}$ at $37^{\circ} \mathrm{C}, 5 \% \mathrm{CO}_{2}$ after which they were washed three times with PBS containing $20 \mathrm{U} / \mathrm{mL}$ heparin (Sigma) to remove surface-bound cationic protein. The cells were trypsinized for 5 $\mathrm{min}$, pelleted in serum-containing DMEM for $3 \mathrm{~min}$ at $500 \mathrm{~g}$, washed with $1 \mathrm{~mL}$ PBS, and pelleted again for $3 \mathrm{~min}$ at $500 \mathrm{~g}$. The cell pellet was resuspended in $100 \mu \mathrm{L}$ PBS. Flow cytometry was performed on a BD Accuri C6 Flow Cytometer at $25^{\circ} \mathrm{C}$. Cells were analyzed in PBS (excitation laser $=488 \mathrm{~nm}$, emission filter $=533$ $+/-30 \mathrm{~nm}$ ). At least 10,000 cells were analyzed for each sample. For background subtraction, wells were treated with clear DMEM only. The average of three untreated wells was subtracted from each +36 GFP conjugate-containing well.

Microinjection of proteins to mouse inner ear. P1-2 Gt(ROSA)26Sor ${ }^{\text {tm } 14(\text { CAG-tdTomato }) H z e}$ mice were used for aurein 1.2+36-GFP-Cre and +36-GFP-Cre injection. The Rosa26tdTomato mice were from the Jackson Laboratory. Animals were used under protocols approved by the Massachusetts Eye \&Ear Infirmary IACUC committee. Mice were anesthetized by hypothermia on ice. Cochleostomies were performed by making an incision behind the ear to expose the cochlea. Glass micropipettes held by a micromanipulator were used to deliver the complex into the scala media, which allows access to inner ear hair cells. The total delivery volume for every injection was $0.4 \mu \mathrm{L}$ per cochlea and the release was controlled by a micromanipulator at the speed of 69 $\mathrm{nL} / \mathrm{min}$.

Immunohistochemistry and quantification. 5 days after injection, the mice were sacrificed and cochlea were harvested by standard protocols ${ }^{47}$. For immunohistochemistry, antibodies against hair-cell markers (Myo7a) and supporting cells (Sox2) were used following a previously described protocol ${ }^{47}$. To quantify the number of $\mathrm{tdT}$ omato positive cells after aurein 1.2-+36-GFPCre and +36-GFP-Cre, we counted the total number of inner and outer hair cells in a region spanning $100 \mu \mathrm{m}$ in the apex, middle, and base turn of the cochlea.

\section{ASSOCIATED CONTENT}

Supporting Information. Additional information and experimental methods. List of all protein constructs included. This material is available free of charge via the Internet at http://pubs.acs.org.

\section{AUTHOR INFORMATION}

\section{Corresponding Author}

*drliu@fas.harvard.edu

\section{AKNOWLEDGMENTS}

This work was supported by the Howard Hughes Medical Institute and the NIH/NIGMS (R01 GM095501) the NIH/NIDCD (R01 DC006908). M.L. was supported by fellowships from Harvard CCB. Y.T. and Y.S were supported by the Frederick and Ines Yeatts Hair Cell Regeneration grant. Y.S. was supported by The National Nature Science Foundation of China (NSFC81300824). Angela Steinauer is a Howard Hughes Medical Institute International Student Research fellow. We are grateful to Thomas Hasaka and Nicola Tolliday of the Broad Institute for assistance with the primary screen.

\section{REFERENCES}

(1) Nelson, A. L.; Dhimolea, E.; Reichert, J. M. Nat Rev Drug Discov 2010, 9, 767.

(2) Huang, C. Current opinion in biotechnology 2009, 20,

692.

(3) Hafler, D. A. Nat Rev Immunol 2007, 7, 423.

2008, 7, 21.

(4) Leader, B.; Baca, Q.J.; Golan, D. E. Nat Rev Drug Discov

(5) Schiffmann, R.; Kopp, J. B.; Austin, H. A.; Sabins, S.;

Moore, D. R.; Weibel, T.; Balow, J. E.; Brady, R. O. JAMA 2001, 285, 2743.

(6) Spiegelman, B. M. Diabetes 1998, 47, 507.

(7) Mali, P.; Esvelt, K. M.; Church, G. M. Nat Meth 2013,

10,957 .

(8) Mueller, J.; Kretzschmar, I.; Volkmer, R.; Boisguerin, P. Bioconjugate Chemistry 2008, 19, 2363.

(9) Appelbaum, Jacob S.; LaRochelle, Jonathan R.; Smith, Betsy A.; Balkin, Daniel M.; Holub, Justin M.; Schepartz, A. Chemistry \& Biology 2012, 19, 819.

(10) Rizk, S. S.; Luchniak, A.; Uysal, S.; Brawley, C. M.; Rock, R. S.; Kossiakoff, A. A. Proceedings of the National Academy of Sciences 2009, 106, 11011.

(11) Hasadsri, L.; Kreuter, J.; Hattori, H.; Iwasaki, T.; George, J. M. Journal of Biological Chemistry 2009, 284, 6972.

(12) Fu, A.; Tang, R.; Hardie, J.; Farkas, M. E.; Rotello, V. M. Bioconjugate Chemistry 2014, 25, 1602.

(13) Pisal, D. S.; Kosloski, M. P.; Balu-Iyer, S. V. Journal of pharmaceutical sciences 2010, 99, 2557.

(14) McNaughton, B. R.; Cronican, J. J.; Thompson, D. B. Liu, D. R. Proceedings of the National Academy of Sciences 2009, 106, 6111.

(15) Cronican, J. J.; Thompson, D. B.; Beier, K. T.; McNaughton, B. R.; Cepko, C. L.; Liu, D. R. ACS Chemical Biology 2010, 5, 747.

(16) Cronican, James J.; Beier, Kevin T.; Davis, Tina N.; Tseng, J.-C.; Li, W.; Thompson, David B.; Shih, Allen F.; May, Erin M.; Cepko, Constance L.; Kung, Andrew L.; Zhou, Q.; Liu, David R. Chemistry \& Biology 2011, 18, 833.

(17) Lawrence, M. S.; Phillips, K. J.; Liu, D. R. Journal of the American Chemical Society 2007, 129, 10110.

(18) Thompson, David B.; Villaseñor, R.; Dorr, Brent M.; Zerial, M.; Liu, David R. Chemistry \& Biology 2012, 19, 831.

(19) Fuchs, S. M.; Raines, R. T. ACS Chemical Biology 2007,

2, 167 .

(20) Pirie, C. M.; Hackel, B. J.; Rosenblum, M. G.; Wittrup, K. D. Journal of Biological Chemistry 201 1, 286, 4165.

(21) Varkouhi, A. K.; Scholte, M.; Storm, G.; Haisma, H.J. Journal of Controlled Release 2011, 151, 220.

(22) Wadia, J. S.; Stan, R. V.; Dowdy, S. F. Nat Med 2004,

10,310 .

(23) Neundorf, I.; Rennert, R.; Hoyer, J.; Schramm, F.; Löbner, K.; Kitanovic, I.; Wölfl, S. Pharmaceuticals 2009, 2, 49.

(24) Sugita, T.; Yoshikawa, T.; Mukai, Y.; Yamanada, N.; Imai, S.; Nagano, K.; Yoshida, Y.; Shibata, H.; Yoshioka, Y.; Nakagawa, S. British journal of pharmacology 2008, 153, 1143.

(25) Zasloff, M. Nature 2002, 415, 389.

(26) Lohner, K.; Blondelle, S. Combinatorial chemistry \& high throughput screening 2005, 8, 241.

(27) Wang, Z.; Wang, G. Nucleic acids research 2004, 32,

D590.

(28) Chen, I.; Dorr, B. M.; Liu, D. R. Proceedings of the National Academy of Sciences 201 1, 108, 11399.

(29) Dijkstra, J.; Van Galen, M.; Scherphof, G. L. Biochimica et Biophysica Acta (BBA)-Molecular Cell Research 1984, 804, 58.

(30) Rozek, T.; Bowie, J. H.; Wallace, J. C.; Tyler, M. J. Rapid Communications in Mass Spectrometry 2000, 14, 2002.

(31) Wegener, K. L.; Wabnitz, P. A.; Carver, J. A.; Bowie, J. H.; Chia, B. C.; Wallace, J. C.; Tyler, M. J. European journal of biochemistry / FEBS 1999, 265, 627.

(32) Balla, M.; Bowie, J. H.; Separovic, F. European

Biophysics Journal 2004, 33, 109.

(33) Fernandez, D. I.; Le Brun, A. P.; Whitwell, T. C.; Sani, M.-A.; James, M.; Separovic, F. Physical Chemistry Chemical Physics 2012, 14, 15739 . 
(34) Sahay, G.; Querbes, W.; Alabi, C.; Eltoukhy, A.; Sarkar, S.; Zurenko, C.; Karagiannis, E.; Love, K.; Chen, D.; Zoncu, R. Nature biotechnology 2013, 31, 653 .

(35) Yu, P.; Liu, B.; Kodadek, T. Nat Biotech 2005, 23, 746.

(36) Holub, J. M.; LaRochelle, J. R.; Appelbaum, J. S.; Schepartz, A. Biochemistry 2013, 52, 9036.

(37) LaRochelle, J. R.; Cobb, G. B.; Steinauer, A.; Rhoades, E.; Schepartz, A. Journal of the American Chemical Society 2015, 137, 2536.

(38) Howarth, M.; Ting, A. Y. Nature protocols 2008, 3, 534.

(39) Akil, O.; Seal, Rebecca P.; Burke, K.; Wang, C.; Alemi, A.; During, M.; Edwards, Robert H.; Lustig, Lawrence R. Neuron 2012, 75, 283. (40) Zuris, J. A.; Thompson, D. B.; Shu, Y.; Guilinger, J. P.; Bessen, J. L.; Hu, J. H.; Maeder, M. L.; Joung, J. K.; Chen, Z.-Y.; Liu, D. R. Nat Biotech 2015, 33, 73.

(41) Taura, A.; Taura, K.; Choung, Y. H.; Masuda, M.; Pak, K.; Chavez, E.; Ryan, A. F. Neuroscience 2010, 166, 1185 .
(42) Izumikawa, M.; Minoda, R.; Kawamoto, K.; Abrashkin, K. A.; Swiderski, D. L.; Dolan, D. F.; Brough, D. E.; Raphael, Y. Nature Medicine 2005, $11,271$.

(43) Thompson, D. B.; Cronican, J. J.; Liu, D. R. In Methods in Enzymology; Wittrup, K. D., Gregory, L. V., Eds.; Academic Press: 2012; Vol. Volume 503, p 293.

(44) Simons, S. S.; Pons, M.; Johnson, D. F. J Org Chem $1980,45,3084$.

(45) Dunkerton, L. V.; Markland, F. S.; Li, M. P. Steroids

1982, $39,1$.

1508.

(46) Kwon, Y. U.; Kodadek, T. J Am Chem Soc 2007, 129,

(47) Sage, C.; Huang, M.; Karimi, K.; Gutierrez, G.;

Vollrath, M. A.; Zhang, D.-S.; García-Añoveros, J.; Hinds, P. W.; Corwin, J. T.; Corey, D. P.; Chen, Z.-Y. Science 2005, 307, 1114.
13

14

15

16

17

18

19

20

21

22

23

24

25

26

27

28

29

30

31

32

33

34

35

36

37

38

39

40

41

42

43

44

45

46

47

48

49

50

51

52

53

54

55

56

57

58

59

60 
Table of Contents graphic:

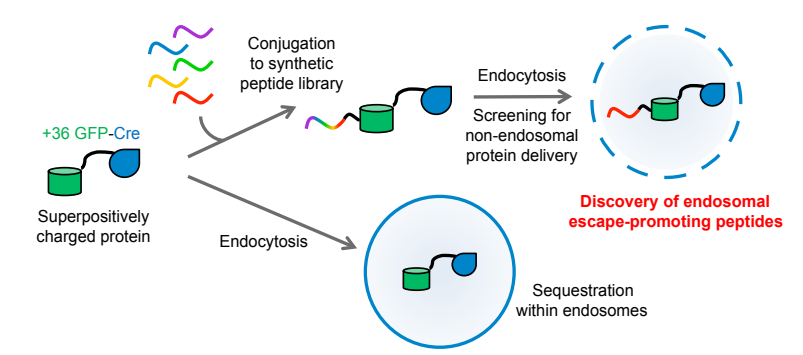

